“Immigration and the Life Course," special issue, Canadian Studies in Population 40, no. 1-2 (2013): 89-102.

\title{
Length of time to first job for immigrants in the United Kingdom: An exploratory analysis
}

\author{
JuYin (Helen) Wong \\ Department of Sociology, Texas A \& M University \\ wong_ju@hotmail.com
}

\begin{abstract}
This study explores whether ethnicity affects immigrants' time to first employment. Many studies on labour/social inequalities focus on modeling cross-sectional or panel data when comparing ethnic minority to majority groups in terms of their employment patterns. Results from these models, however, do not measure the degree of transition-duration penalties experienced by immigrant groups. Because time itself is an important variable, and to bridge the gap between literature and methodology, a lifecourse perspective and a duration model are employed to examine the length of transition that immigrants require to find first employment.
\end{abstract}

Keywords: immigrants, first employment, duration analysis.

\section{Résumé}

Cette étude essaie de déterminer si l'origine ethnique a un effet sur le premier emploi d'un immigrant. Beaucoup d'études sur les inégalités sociales et relatives au travail ciblent les modèles les données en coupe transversales ou recueillies au moyen d'un panel pour comparer une minorité ethnique aux groupes majoritaires sur le plan des modèles d'emploi. Cependant, les résultats de ces modèles ne mesurent pas le degré de pénalités subies en termes de durée de transition par les groupes d'immigrants. Comme le temps en soi est une variable importante, etpour combler l'écart entre la théorie et la pratique, une perspective de vie entière et un modèle basé sur la durée sont utilisés pour examiner la durée de la transition dont les immigrants ont besoin pour trouver leur premier emploi.

Mots-clés : immigrants, premier emploi, analyse de durée.

\section{Introduction}

People move to a new country for various reasons, including socioeconomic reasons, such as seeking employment, starting a new life, or sending remittance home; others may move to seek political asylum. There are also some who cannot even provide any clear explanation as to why they have left their homes for a new place, where they have to start all over. Whatever the reasons are, it is sensible to say that all these people move because they are motivated by the belief and hope for a better, more successful future than their home country can offer. Thus, these individuals' integration into the labour market is important to equality and diversity policymakers who seek to promote the fair treatment of immigrant workers, as well as their successful progression in the labour market in obtaining a job after their arrival (Syed 2008).

This study contributes to immigration literature by employing lifecourse perspectives and duration models to explore "how quickly" or "how slowly" it takes for ethnic immigrant groups and cohorts in the United Kingdom (UK) to change from the "first time seeking a job" status to their first employment. In addition, it explores whether immigrants tend to engage in low-end or high-end jobs for their first employment.

\section{Theoretical considerations}

\section{Job allocation and search}

For immigrants, the allocation process between jobs and workers is partly shaped by "the interplay of opportunity structures determined by employers' preferences and job resources on the one side, and job seekers' preferences and personal resources, which determine their choice of opportunities, on the other" (Kogan and Unt 2008: 3). 
Kogan and Unt call this phenomenon "the micro-sociological and micro-economic two sided search and matching models" (2008: 3). The majority of job seekers seek to find jobs that will bring them "the most adequate returns [the time, monetary and mental or physical effort] on investments [they have put] in education" (Kogan and Unt 2008: 3). In the case of immigrant job seekers, they not only have the previously mentioned goals, but also hope that sometime after arrival they will find jobs with the same or higher level of status relative to the ones they had in their home countries.

Within the recruitment process, employers are likely to rank job applicants in queues based on their suitability for a specific position (Reskin and Roos 1990). Educational credentials, vocational specificity, and relevant work experience play an important role in the screening process, as they represent applicants' productive capabilities and potential. However, from the employer's standpoint, unless the skill sets and qualifications are applicable or transferrable to the UK labour market context, employers are reluctant to offer employment to these immigrant job seekers, as their productivity will not be conceived as comparable to their British-born or "White British" counterparts, who have the country-specific skills necessary to work in Britain (called comparable worth theory by England 1997 and others). Therefore, for immigrant job seekers, the chances of getting hired in the mainstream labour market, particularly in highly-paid, professional, or managerial jobs, become minimal (Reitz 2007). Furthermore, during the job search process, they are likely settling with low-end or no jobs during the course of their job search, particularly during economic recessions (referred to as "skill mismatch and segmentation theory" by Alba and Nee 2005, among others).

Since immigrant job seekers may have unrecognized qualifications, they may therefore face prejudice or be stereotyped by employers as less qualified job applicants because of their country of origin. This prejudice may involve biases against immigrants' individual attributes or abilities, their likelihood of fitting into the workforce, or the quality of their education obtained in other countries. In the case of non-white immigrants, they are likely to face greater exclusion from the job market than immigrants who do not come from an ethnic minority (Heath and Cheung 2006). There is strong evidence of ethnic discrimination in the labour market, both in the UK and in other countries. An experimental study done by Oreopoulos (2009) for example, shows that ethnic-sounding names along with foreign credentials on the resumes expose these ethnic minority immigrants as non-native English speakers; their applications are likely turned down during the pre-screening process, before they are given the chance for a face-to-face interview to determine if they have the right language skills and qualifications. Based on the above considerations, the length of time it takes immigrants to find first employment is likely to differ based on the immigrant job seekers' country of origin, and on prejudices and stereotypes held by employers. Consequently, they are likely to be not uniform across ethnic groups, thus highlighting the limitations of drawing dichotomous comparisons between majority and minority populations or white and non-white groups.

\section{Structural proximity of sending and receiving country}

Raijman and Semyonov (1995) thus argue that the proximity of the structural distances of the economic, educational, and occupational systems between immigrants' home country and receiving country is important in shaping the experience of immigrants' economic and labour assimilation into their host country. The narrower the structural distances between the two, the greater the transferability of immigrants' human capital resources, and the more likely are their skills and credentials to be recognized as equivalent to the British counterparts.

One possible corollary is that immigrants coming from English-speaking countries are likely to have higher levels of English proficiency and will have the fastest economic progression, since these immigrants are less likely to have language barriers that prevent them from getting a job. However, because there are substantial variations in accents English, the effect of subtle accents likely has various impacts, depending on the job sector (e.g., English with a foreign accent may be devalued in the service industries more so than in engineering or other technical jobs). Therefore, based on these rationales, immigrants coming from the USA, Canada, and Australia are then expected to take the least time to find their first employment compared to other immigrant groups. This is in large part due to the fact that not only their language but also the economic, political, educational, and normative systems of their country of origin are almost identical to the systems of the UK. In contrast, immigrants coming from less developed, non-English speaking areas such as Pakistan and Bangladesh are expected to take the longest time to find their first employment in the UK after their arrival. 
Wong: Length of time to first job for immigrants in the United Kingdom: An exploratory analysis

Nevertheless, Raijman and Semyonov assert that even where the gap of the structural systems between immigrants' home country and receiving country is small, the "transferability of skills and human capital resources from one society to another [may still well] differ across occupational labor markets" (1995: 377). For example, professionals whose occupations have no barriers or have only partly effective barriers with high skills transferability to other occupations — such as engineers, technicians, scientists, and craftsmen—likely find their skills and knowledge highly transferable to a new settled country and find jobs in the occupations for which they are trained, or take on jobs in other comparable occupations. However, the occupations of lawyer, accountant, and medical doctor, which have highly effective barriers with low skills transferability to other occupations, are not readily transferrable as the UK requires these immigrant job seekers to possess a knowledge of laws, rules, and regulations that is country-specific, as well as licensing permits, before they can practice in the UK (Raijman and Semyonov 1995; Ahamad et al. 2003).

\section{Retraining}

Because investment in education and training is an investment in human capital as well as a person's relative position in the labour market, immigrants who are often willing to spend the time and effort to acquire additional skills or credentials after their arrival will have expanded job skills and become portfolio workers (Giddens and Griffiths 2006). They have wider job options to choose among different occupations. Employers are also likely to perceive them as more productive and economical cost-wise; hence, these workers will have a higher likelihood to be employed in the receiving country. However, people who are poorly educated or unskilled in their home country may not become fully proficient in adapting to their new settlement. Therefore, they may remain disadvantaged in their employment trajectories, no matter how long they stay in the UK (referred to as "deficit theory" by Singer and Willet 2003 and others).

\section{Duration of stay}

At the beginning of resettlement, newcomers likely have an information deficit (Shields et al. 2006). They do not have enough experience of UK society, nor do they have the relevant information about employment and settlement; they do not know what to expect in the employment market, what is realistic to achieve in the UK, what kinds of government support and financial assistance are available, and they have not yet devised employment strategies and garnered advice. However, common wisdom tells us that over time, people will gradually learn to adapt to their surroundings, and develop either kin or non-kin networks (referred to as "social capital theory" by Lin et al. 2001 and others), i.e., friends, neighbours, work, and colleague networks. This process allows the establishment of bonding, helps bridge social ties between and across people, and provides opportunities as social support, a safety net in time of need, and even information and employment in their relational communities (Hofferth and Iceland 1998; Lin et al. 2001; Beaudoin and Thorson 2004).

Much research has shown that before moving into a new country, a large proportion of immigrants already have kin and friendship networks in the country in which they are going to settle (a case more likely to be happening on the later waves of immigrants instead of the first wave of immigrants; Solomos 1989; Anwar 2003). These social networks become latent resources that help immigrants overcome barriers to getting a job in their newly settled country. For example, we can see that many Chinese, Pakistani, and Bangladeshi immigrants arriving in the UK can easily find jobs working in restaurants within their community groups (Webster 1998, 2006). Hence, those who have already stayed some time and/or already have some form of social support system in the UK are expected to be, on average, less likely to experience information deficit, and encounter difficulties in settlement. They, then, may have a higher likelihood as well as take less time in finding their first job, provided that other factors, such as levels of qualifications and English language, are also being taken into account.

Though duration of stay, along with social capital and various factors, can be facilitators in assisting immigrants to find their first employment, studies have shown a linear effect of the duration of joblessness on the length of time it takes immigrant job seekers to find their first job. Bjørnstad (2006) found that the longer immigrant job seekers experience joblessness, "the more likely is a reduction in feelings of personal efficacy" (referred to as "the scarring effect" by Bjørnstad and others). These immigrant job seekers are more likely to become discouraged workers and have a higher probability of signaling a negative effect to employers. Employers may feel that these immigrants are unskilled, and this might, in turn, cause further difficulties for these immigrant job seekers to find employment in the future (Bjørnstad 2006). 


\section{Socio-demographic characteristics}

Several other factors are expected to influence the duration to first employment for UK immigrants.

Age of entry to the receiving country's labour market is likely to present a concave function on immigrants' length of time of being hired in the labour force, since the younger immigrants are likely to be in education, and the older ones are likely to be perceived by employers nearing the age of retirement and stereotyped as less productive cost-wise. However, little is known about the precise age points when immigrants are more likely to be hired (Ochsen 2009). On the other hand, immigrants who arrived in the UK as children or before their adolescence have rather different trajectories from those who arrive as adults. They may have gone through the British education system, acclimatized to British culture, and know the English language, just like the natives or descendants of first-generation immigrants born in the UK. Once they turn 16 or reach prime working age, these immigrants are also expected to do substantially better as opposed to those sharing similar characteristics but having moved to the UK when they were adults. Therefore, longer duration of stay seems to benefit their career more than for older immigrants, who in contrast face greater difficulties in adjusting to the new labour market.

Nevertheless, because there are age-graded roles and behaviours for men and women, much research shows immigrant women in general suffer a double disadvantage when competing for jobs with their male counterparts (Raijman and Semyonov 1997; Hutchinson 2004). They are found to be, in general, the least likely to be in employment and economically active among all labour force participants (Clark and Drinkwater 2008). Raijman and Semyonov (1997) attribute immigrant women's low labour participation to several factors. First, the occupational structure in society is gender-segregated, with labour opportunities available to women concentrated to a small number of occupation categories. Second, since opportunities are already limited, immigrant women will face tighter and tougher labour opportunities in the host country, as their human capital resources are not readily transferable. Next, women are more likely to assume traditional family roles and responsibilities than men. In other words, with marriage and birthing, immigrant women, like all other women, are less likely to join the labour force and become economically active. However, the rate of labour (non-)participation differs across ethnic and geocultural groups, depending on their qualifications, English proficiency, and the openness of their culture to accepting (married) women and mothers in the labour force.

\section{Context of place and time}

Besides the aforementioned factors, immigrants' employment and earnings are affected by the local and regional conditions of the labour market where they seek work, such as structural changes in the supply and demands of job/labour skills in businesses (Pastor and Marcelli 2000). Therefore, they are expected to experience difficulties in securing a job in less favourable market conditions, regardless of their qualifications and how well they are connected (i.e., social networks). As well as location, the context of time of settlement also plays an important role in explaining their employment situation. The types of immigrants moving into the UK differ significantly across different time periods. Consequently, the types of occupations immigrants engage in and the length of time it takes them to find first employment vary depending on their time of entry to the UK.

\section{Historical context of UK immigration to $1995^{1}$}

After the Second World War, the UK government established the 1948 British Nationality Act to limit the entry of non-British subjects to the UK (Solomos 1989). Citizens of the UK and its colonies, as well as citizens of Commonwealth nations, had the right to settle and work within the country. Because of labour shortages, a large number of immigrants outside were recruited to "fill those gaps in the UK labour market created not only by the effects of war, which resulted in the loss of many of Britain's active working population, but also by the upward movement of a significant proportion of the indigenous workforce" (Daye 1994). The jobs these immigrants took on were largely in unskilled and manual work.

The increase of non-white immigrants during the 1950s created a concern in the British general public (Anwar 2003). In 1958, a series of race riots broke out (Solomos 1989). The British government responded by implementing the 1962 and 1968 Commonwealth Immigrants Acts to restrict the entry of Commonwealth citizens. A large number of third-world Commonwealth migrants began to flow into the UK, trying to beat the impending ban (Anwar 2003).

1. A general historical immigration background of the United Kingdom is provided up till 1955, because the survey used for the empirical analysis is collected from people living in Britain between 1994 and 1995. 
These immigrants were primarily from the West Indies, India, Pakistan, and Bangladesh (Castles and Kosack 1973). Most of them were unskilled or semi-skilled manual workers, working primarily in the garment industry.

Apart from immigration from the West Indies and Indian sub-continent Commonwealth immigrants, the UK received large numbers of East Africa Asians expelled from Kenya by Kenyetta, and from Uganda by Idi Amin, between the mid-1960s and early 1970s (Cutts 2000; Robinson 2003). As a result, immigration resurfaced as a major political issue. When these refugees entered the country, many ended up being stranded in transit camps for a long time. In 1971, the Conservative government introduced the 1971 Immigration Act, which stipulated that only indigenous British had the right of abode (Solomos 1989). The colonial or Commonwealth citizens could no longer enter the UK without providing evidence they had the right of abode.

On January 1, 1973, the UK government signed the Treaty of Rome and formally became part of the European Union (called the Common Market at that time). This treaty laid a basis for workers of member states to come to the UK more freely, allowing for potentially millions of white European immigrants to move into the country. In the meantime, the UK began to experience a major economic downturn (Reid 1982). Its industries started waning; many had to shut down. Accordingly, many British people were laid off. They began to fear job competition from the non-whites, and feel the government should take care of their interests first, such as helping them find employment and giving them council housing first (Reitan 2003). Consequently, a further stage of non-white immigration control was implemented after Margaret Thatcher was elected as Prime Minister in 1979 (Spencer 1997). The 1981 British Nationality Act was then passed, with only spouses and dependent children of the UK citizens and residents having the right to settle in the UK (Stein 1995). Later, the 1988 Immigration Act abolished the right of entry and right of abode to dependents of Commonwealth citizens who settled in the UK before 1973 (Barnett 2002).

In 1991, John Major succeeded Thatcher as the leader of the Conservative Party. The British government was more open to cultural diversity and immigrants' naturalization applications (Layton-Henry 2004). Accordingly, there was an overall improvement in immigrants' integration into British society, because the increase in the number of immigrants becoming citizens implied a large number of the immigrants in this period having the same citizen rights as the native British. They could stay in the UK permanently, travel in and out of the UK without restriction, vote for political parties that would protect their interests, and apply for government jobs or council housing (Directgov 2010; Layton-Henry 2004). Nevertheless, there was a "considerable divergence between major ethnic groups in terms of [their] employment [and labour participation]" between 1991 and 1994 (Layton-Henry 2004: 311). Chinese men and women, as well as African Asian men, were more likely to be in professional, managerial, and employer positions in comparison to white men and women. Indians and Caribbeans were likely to be in middle positions. In contrast, Pakistanis and Bangladeshis were found to be severely disadvantaged; they were disproportionately concentrated in manual, semi-skilled work. Men of both groups had much higher unemployment rates compared to other ethnic minority groups; women were also much more likely to be unemployed or economically inactive than women from other groups.

\section{Data and variables}

The research questions are investigated with data from the Family and Working Lives Survey (FWLS). The sample consists of information from 11,237 respondents, drawn from people born between 1924 and 1978, living in Britain $^{2}$ between 1994 and 1995 (Rohwer 1996; Mckay 1997). A total of 2,094 individuals were born outside Britain, with 1,977 having job grids. This survey offers a unique opportunity for the analysis of immigrants' time to first employment, because it contains a variety of individual information such as sex, ethnic/geo-cultural backgrounds, marital status, English skill level, year of birth, and year of entry, as well as retrospective, ${ }^{3}$ longitudinal information

2. Although the FWLS selects a sample only from Britain, it constitutes a major part of the UK. The main difference is that Britain (or Great Britain) does not include Northern Ireland.

3. Because of the retrospective nature of FWLS, there is an issue about the accuracy of the recall date. About 50 per cent of the immigrants (26 per cent for the analytical sample in Cox models) have problems in remembering accurately the date of their arrival. These people answered that their arrival date occurs after the date of their first state of employment activity in Britain. According to Dr. Paul Allison, though, in principle it is possible to use multiple imputation to impute immigrants' date of arrival, with the condition that they occur before their first (un)employment state, imputing event dates for survival analysis is hard to do in a way that does not lead to bias. To correct this problem, the dates of arrival for these people have been re-adjusted and re-dated to the date of their first employment state. This assumes the date of first state of employment activity is correct. 
concerning immigrants' area of residence, education, spells of (un)employment, and occupation status in Britain since entry. Table 1 shows the socio-demographic characteristics of the immigrant sample.

Because not all immigrants are economically active when arriving in Britain, nor are they all ready to work for a job at the time of arrival, given the complexity, for analyzing how long it takes immigrant workers to find their first job, the risk set in this analysis is defined as those who have not yet experienced any employment in Britain, but who are looking for work and have the possibility of experiencing first employment at the beginning of the interval $(\mathrm{n}=910)$.

Accordingly, there are two states of interest for the analysis. First time seeking a job is the immigrants' origin state, which is the status of their first entry to the British labour market after their arrival in Britain. We call it time zero $(\mathrm{t}=0)$. The second state is the terminal state, when immigrants have become employed for the first time in Britain $(t=T)$. The event of interest is thus the time respondents find their first job, whereas the duration of interest is the calendar months from their first time seeking a job status $(t=0)$ to their first employment state $(\mathrm{Y}=1, \mathrm{n}=875)$ in a single-spell, two-state event history model. Besides using calendar months as the time scale for duration analysis, age is also used to measure the length of time-to-event to examine age-specific incidence functions (Machin et al. 2006). For immigrants who have experienced an event, their occupational employment is then converted into the Standard International Occupational Prestige Scale (SIOPS) developed by Ganzeboom and Treiman (1996), to measure whether immigrants are likely engaged in lower or higher ranks of occupation for their first job.

\section{Methods}

Many studies on labour and social inequalities focus on modeling (repeated) cross-sectional or panel data when comparing minorities to the majority ethnic groups in terms of their employment outcome and income level (Heron 2001; Fuller 2011). Results obtained from these studies, thus, only provide partial snapshot pictures of dynamic processes, which do not measure the degree of transition-duration (i.e., length of time for a transition to take place) penalties experienced by immigrant groups (Lochhead 2003; Grenier and Xue 2009). Cross-sectional estimates may either underestimate or overestimate the employment and income status of immigrants, whereas panel models (either random or fixed effects) often remove the effect of time by either time demeaning (FE) or quasi-time demeaning (RE), and the calculations derived detrend the data by subtracting the average effect of time from the data (Wooldridge 2008). Because time itself is an important variable, a duration model is more appropriate; thus, event history analysis is employed, with a frailty term to account for unobserved individual and geographic heterogeneities (Singer and Willett 2003).

Cox's semiparametric models have been chosen to fit the duration analysis. The hazard rate $h(t)$ is the product of a non-parametric baseline hazard $h_{0}(t)$ and a parametric function of explanatory covariates $X$ and corresponding parameters $\beta$, such that we have:

$$
h(t, x)=h_{0}(t) \exp \left(\beta^{\prime} X\right)
$$

This technique has several modeling advantages over other methods. It requires minimal assumptions about the distribution of event times, allows for modeling the time-varying or time-dependent variables, has the ability to handle censored cases or ties for both continuous and discrete data, as well as the capacity to fit frailty models (Allison 1984, 2010). Five models have been selected to present the effects of the predictors on immigrants' unemployment duration and occupational prestige scale.

Table 2 has three models, which are two-state duration models that presume the types of jobs in which immigrants engage are indistinguishable from each other. The first model is a main effect model ${ }^{4}$ that looks at the independent net effect of each predictor on the log cumulative hazard function, whereas the second model is a frailty model, ${ }^{5}$ testing whether immigrants living in some counties are more failure-prone than immigrants living in other

4. Age-squared has been tested and found to be statistically non-significant. Other interaction effects, such as education and language fluency, have also been tested. Because the sample size is limited in relation to the number of interaction terms to be estimated, the survival estimates of interaction effects are found to be statistically non-significant.

5. Because Cox models are an approximation of the (correct) parametric survival models, Weibull frailty and discretetime frailty models (both logit and complementary log-log) have also been estimated. The frailty terms turn out to be statistically significant (Kleinbaum and Klein 2005). Thus, cluster effects are taken into account in linear regression models to control unobserved heterogeneity. 
Table 1. Number and percentage of immigrants, by descriptive characteristics of the sample with work grid.

Total

SIOPS - mean; $\min / \max$

Sex (fixed)

Male

Female

Ethnicity (fixed)

White

Eire

Black African/Black Caribbean/Black other

Pakistani

Bangladeshi

Indian

Other

Country of origin (fixed)

US/Canada/Australia/New Zealand

Latin America

Northern/Western Europe

Eastern/Southern Europe

Africa

South Asia

East/South East/West Asia and other

Age at arrival (fixed)

Mean; $\min / \max$

Age at entry (fixed)

Mean; $\min / \max$

Marital status at entry (time-varying)

Independent/single

Divorced/separate/widowed

Married/cohabiting

Total \# of children during stay in Britain (fixed)

Mean; $\min / \max$

English fluency (fixed)

Yes

No

Education at entry (time-varying)

None

Secondary School

College

University/polytechnic

Government/training schemes

In education at entry (time-varying)

Yes

No

Period of arrival (fixed)

$<$ Jan 1, 1949

Jan 1, 1949 (British Nationality Act 1948 became effective)-Dec. 31, 1957

Jan 1, 1958-June 30, 1962

July 1, 1962 (Commonwealth Immigrants Act

1962 became effective)-Aug 1, 1965

Aug 2, 1965 (British Nationality Act 1964

became effective)-Feb 29, 1968

March 1, 1968 (Commonwealth Immigrants Act

1968 became effective)-Dec 31, 1972

Jan 1, 1973 (Immigration Act 1971 became

effective)-Dec 31, 1982

Jan 1, 1983 (British Nationality Act 1981 became effective)-July 9, 1988

July 10, 1988 (Immigration Act 1988 became effective)-date of interview

\begin{tabular}{crrrrr}
\multicolumn{2}{c}{ Economically active } & \multicolumn{2}{c}{ Economically inactive } & \multicolumn{2}{c}{ Total } \\
\hline \multicolumn{1}{c}{$\%$} & \multicolumn{1}{c}{$\%$} & \multicolumn{1}{c}{$\%$} & $\mathrm{~N}$ & \multicolumn{1}{c}{$\%$} \\
\hline 910 & & 1067 & & 1977 & \\
$35.57 ; 15 / 78$ & & & & & \\
& & & & & \\
501 & 55.05 & 400 & 37.49 & 901 & 45.57 \\
409 & 44.95 & 667 & 62.51 & 1076 & 54.43 \\
& & & & & \\
153 & 16.81 & 83 & 7.78 & 236 & 11.94 \\
45 & 4.95 & 16 & 1.50 & 61 & 3.09 \\
157 & 17.25 & 141 & 13.21 & 298 & 15.07 \\
140 & 15.38 & 265 & 24.84 & 405 & 21.95 \\
148 & 16.26 & 330 & 30.93 & 478 & 20.49 \\
237 & 26.04 & 197 & 18.46 & 434 & 24.18 \\
30 & 3.30 & 35 & 3.28 & 650 & 3.29 \\
& & & & & \\
28 & 3.08 & 19 & 1.78 & 47 & 2.38 \\
139 & 15.27 & 134 & 12.56 & 273 & 13.81 \\
91 & 10 & 35 & 3.28 & 126 & 6.37 \\
31 & 3.41 & 29 & 2.72 & 60 & 3.03 \\
125 & 13.74 & 72 & 6.75 & 197 & 9.96 \\
456 & 50.11 & 747 & 70.01 & 1203 & 60.85 \\
40 & 4.40 & 31 & 2.91 & 71 & 3.59
\end{tabular}

$13.52 ; 0.04 / 55.16$

$19.05 ; 12.19 / 55.16$

$\begin{array}{rr}798 & 87.69 \\ 8 & 0.88\end{array}$

$102 \quad 11.21$

$2.18 ; 0 / 12$

$413 \quad 45.38$

$497 \quad 54.62$

109

437

193

87

73

252

658

68

103

90

81

90

$142 \quad 15.60$

240

51

45
$22.48 ; 0.05 / 60.06$

$16.43 ; 0.00 / 45.88$

997

0

66

$2.75 ; 0 / 12$

564

503

52.86

47.14

598

370

56.10

34.70

5.40

1.70

2.10

25.50

74.50

795

96

9.00

16.40

6.75

5.44

5.72

14.06

150

298

27.93

7.87

6.84
$18.35 ; 0.04 / 60.06$

$17.64 ; 0.00 / 55.16$

$\begin{array}{rr}1795 & 90.79 \\ 8 & 0.40 \\ 168 & 8.50\end{array}$

$2.49 ; 0 / 12$

977

1000

49.42

50.58

$709 \quad 35.86$

$8717 \quad 41.33$

$252 \quad 12.75$

$105 \quad 5.31$

$90 \quad 4.55$

$559 \quad 28.28$

$1418 \quad 71.72$

$164 \quad 8.30$

$278 \quad 14.06$

$\begin{array}{ll}162 & 8.19\end{array}$

$139 \quad 7.03$

$151 \quad 7.64$

$292 \quad 14.77$

$538 \quad 27.21$

$135 \quad 6.83$

$118 \quad 5.97$ 
Table 2. Hazard ratios of time to first employment since seeking employment.

\begin{tabular}{|c|c|c|c|c|}
\hline \multirow[b]{3}{*}{ Sey (Ref. Mole) } & \multicolumn{2}{|c|}{ Model 1} & \multirow{2}{*}{$\begin{array}{c}\text { Model } 2 \\
\text { Frailty I } \\
\text { B (SE) }\end{array}$} & \multirow{2}{*}{$\begin{array}{c}\text { Model } 3 \\
\text { Frailty II } \\
\text { B (SE) }\end{array}$} \\
\hline & $\begin{array}{c}\text { Main Effect I } \\
\text { B (SE) }\end{array}$ & $\begin{array}{c}\text { Main Effect II } \\
\text { B (SE) }\end{array}$ & & \\
\hline & & & & \\
\hline Female & $0.0351(0.0755)$ & $0.0569(0.0753)$ & $0.0357(0.0755)$ & $-0.4030 *(0.0865)$ \\
\hline \multicolumn{5}{|l|}{ Ethnicity (Ref: Indian) } \\
\hline White & $0.0006(0.1213)$ & & $0.0023(0.1215)$ & $-0.2602(0.1558)$ \\
\hline Eire & $-0.3269(0.1868)$ & & $-0.3227(0.1871)$ & $-0.1694(0.2129)$ \\
\hline Black African/ Black Caribbean/ Black Other & $-0.2699 *(0.1287)$ & & $-0.2646 *(0.1291)$ & $-0.7712 *(0.1488)$ \\
\hline Pakistani & $-0.2071 *(0.1147)$ & & $-0.2082 *(0.115)$ & $-0.4410 *(0.1381)$ \\
\hline Bangladeshi & $-0.1956(0.1182)$ & & $-0.1888(0.1189)$ & $-0.1557(0.1392)$ \\
\hline Other & $-0.1293(0.2048)$ & & $-0.1230(0.2052)$ & $0.1111(0.2426)$ \\
\hline \multicolumn{5}{|l|}{ Country of origin (Ref: South Asian) } \\
\hline US/Canada/Australia/New Zealand & & $0.0755(0.2139)$ & & \\
\hline Latin America & & $-0.1755(0.1327)$ & & \\
\hline Northern/Western Europe & & $-0.0982(0.1396)$ & & \\
\hline Eastern/Southern Europe & & $0.2505(0.1933)$ & & \\
\hline Africa & & $-0.0316(0.1092)$ & & \\
\hline East/South East/West Asia and Other & & $0.0960(0.1734)$ & & \\
\hline Age at Arrival & $0.0413 *(0.0070)$ & $0.0411 *(0.0068)$ & $0.0414 *(0.0070)$ & $0.1150 *(0.0065)$ \\
\hline Age at Entry & $-0.0743 *(0.0107)$ & $-0.0731 *(0.0105)$ & $-0.0743 *(0.0107)$ & \\
\hline \multicolumn{5}{|l|}{ Marital status at entry (Ref: Other) ${ }^{\mathrm{a}}$} \\
\hline Married/ Cohabiting & $-0.3149 *(0.1244)$ & $-0.3355 *(0.1244)$ & $-0.3160 *(0.1245)$ & $-1.8019 *(0.1405)$ \\
\hline \multicolumn{5}{|l|}{ English fluency (Ref: No) } \\
\hline Yes & $0.1437(0.1002)$ & $0.1649(0.0964)$ & $0.1419(0.1004)$ & $0.4655 *(0.1124)$ \\
\hline \multicolumn{5}{|l|}{ Education at entry (Ref: Secondary School) } \\
\hline None & $-0.3832 *(0.1196)$ & $-0.4232 *(0.119)$ & $-0.3844 *(0.1197)$ & $-1.7390 *(0.1615)$ \\
\hline College & $0.0911(0.0900)$ & $0.0790(0.0902)$ & $0.0918(0.0901)$ & $-0.3563 *(0.1050)$ \\
\hline University/ Polytechnic & $0.3022 *(0.1339)$ & $0.3306 *(0.1339)$ & $0.3027 *(0.1340)$ & $-0.3983 *(0.1401)$ \\
\hline Government/ Training schemes & $-0.0787(0.1413)$ & $-0.0804(0.1410)$ & $-0.0756(0.1414)$ & $-1.1052 *(0.1535)$ \\
\hline \multicolumn{5}{|l|}{ In education at entry (Ref: No) } \\
\hline Yes & $-0.1771 *(0.0823)$ & $-0.1844 *(0.0823)$ & $-0.1788 *(0.0824)$ & $0.6580 *(0.0884)$ \\
\hline \multicolumn{5}{|l|}{ Period of Arrival (Ref: Jan 1, 73-Dec 31, 82) } \\
\hline$<\operatorname{Jan} 1,1949$ & $0.2790 *(0.1582)$ & $0.3284 *(0.1554)$ & $0.277 *(0.1583)$ & $1.4474 *(0.1852)$ \\
\hline Jan 1, 1949-Dec 31, 1957 & $0.1699(0.1295)$ & $0.1820(0.1302)$ & $0.1679(0.129)$ & $0.6852 *(0.1498)$ \\
\hline Jan 1, 1958-June 30, 1962 & $0.1615(0.1332)$ & $0.1967(0.1327)$ & $0.1614(0.1333)$ & $-0.0528(0.1540)$ \\
\hline July 1, 1962-Aug 1, 1965 & $0.1971(0.1379)$ & $0.2241(0.1367)$ & $0.1993(0.1380)$ & $0.3663(0.1562)$ \\
\hline Aug 2, 1965-Feb 29, 1968 & $0.2589 *(0.1306)$ & $0.2662 *(0.1307)$ & $0.2600 *(0.1307)$ & $1.2166 *(0.1418)$ \\
\hline March 1, 1968-Dec 31, 1972 & $0.0969(0.1126)$ & $0.1260(0.1119)$ & $0.0984(0.1127)$ & $-0.0081(0.1337)$ \\
\hline Jan 1, 1983-July 9, 1988 & $-0.1021(0.1672)$ & $-0.1336(0.1664)$ & $-0.1033(0.1673)$ & $-0.1320(0.1892)$ \\
\hline July $10,1988-$ Date of interview & $-0.3374 *(0.1807)$ & $-0.3717 *(0.1792)$ & $-0.3355 *(0.1808)$ & $-0.0581(0.2192)$ \\
\hline Frailty term (normally distributed) ${ }^{\mathrm{b}}$ & & & $0.0013(0.0080)$ & $0.3692 *(0.1090)$ \\
\hline \multicolumn{5}{|l|}{ Goodness-of-fit } \\
\hline$-2 \mathrm{LL}$ & $10,036.800$ & $10,042.394$ & & \\
\hline AIC & $10,084.800$ & $10,090.394$ & & \\
\hline $\mathrm{BIC}$ & $10,198.995$ & $10,204.588$ & & \\
\hline RIC & $10,189.347$ & $10,194.941$ & & \\
\hline
\end{tabular}

Notes: Dunn-Šidák correction is employed to counteract the problem of multiple comparisons (Dunn 1961). To compromise between Type I and Type II errors, a separate family-wise error rate, $\alpha$, is set to each control variable (Dunnett 1964). Because there is only one coefficient to estimate for sex, age at arrival, age at entry, marital status, school participation and English fluency, the conventional 0.05 significance level (*) is used. For ethnicity and country of origin, the overall $\alpha$ is set to 0.35 and the calculated $\beta$ (the significance threshold) is 0.07 . For level of education and period of arrival, $\alpha$ is set to 0.20 and 0.50 , with $\beta$ being 0.05 and 0.08 , respectively.

a. Because of the sample sizes for economically active individuals who are divorced, separated, and widowed are small, they are grouped together with those who are independent and single. They are labelled as Other in the marriage reference category.

b. No information criteria are reported in the outputs of SAS's PHREG for analyzing a Cox frailty model; as a result, we are unable to compare models and decide which model is a better fitting model. 
counties. These two models use calendar months as the time scale for analysis. The third model is also a frailty model, but using age as the time scale to measure time-to-event.

Table 3 reports two linear regression models estimating immigrants' occupational scores. Model one looks at the determinants on the scores of those immigrants who have found a job ( $\mathrm{n}=875$, and 578 of them have a score), while controlling unobserved heterogeneities of people living in different counties. The mixed linear regression would be

$$
Y=X \beta+Z b+\varepsilon
$$

where $Z$ is a matrix of random effect covariates and $b$ is the vector of random effects (Laird and Ware 1982).

Because the analysis only considers economically active workers, these immigrants may differ in unmeasured ways from immigrants who do not work. Hence, a selection problem likely exists. The estimates of the previous model are likely to be biased. A two-stage cluster Heckman correction model is run to account for sample selectivity (Heckman 1979; Golder 2012). Since Bangladeshi and Pakistani immigrants, and those having children, tend to be associated with lower labour force participation, they are inserted in the selection equation:

$$
U=w \gamma+u,
$$

where $U$ represents the likelihood of immigrants participating the labour force, and $w$ is the selected factors that influence their decisions to work.

\section{Findings}

Table 2 presents the results of Cox models. ${ }^{6}$ The predictors of Models I and II show similar patterns on the (log) hazard ratio of immigrants finding their first employment. Sex plays no effect on the duration of immigrants finding first jobs, while holding other variables constant. Among ethnic immigrants, Black African/Black Caribbean/Black Other, and Pakistani immigrants are the ethnic groups that take significantly more time finding their first employment. The geo-cultural groups that immigrants belong to do not report significant evidence in having an impact on immigrants' duration to first employment. Surprisingly, English fluency also does not play an effect on immigrants' duration to first employment. This is likely because immigrants might seek work in co-ethnic labour markets through ethnic newspapers or their ethnic ties (Sanders et al. 2002). Consequently, they are not required to be fluent in the English language for their job appointment.

Immigrants' age at arrival, age at job entry, marital status, education level, and current school participation, on the other hand, demonstrate significant effects in predicting immigrants' speed to their first employment in Britain. The older immigrants are when they arrive, the more likely they are to experience first employment, whereas the older they are when they seek employment at time zero, the longer it takes for them to change from unemployment to employment. Being married or in a cohabiting relationship contributes to immigrants' slower trajectory to obtaining a first job in Britain than immigrants who are independent, single or divorced, separated, and widowed, as the former individuals may have more familial obligations than the latter. Participating in some sort of education program during the job search also delays immigrants' job obtainment than those who are not. The qualification variable has supported the hypothesis that immigrants who are more qualified or have a university/polytechnic degree take less time to find their first job than those who are poorly qualified.

Moreover, period of arrival appears to show some effects in affecting immigrants' pace of finding jobs in Britain, even though the immigrant sample of earlier immigration cohorts may not be as representative as cohorts coming in later periods. Immigrants who enter the country before January 1, 1949, take significantly less time to find their first jobs than those who come in other immigration periods. This may have to do with the public's greater tolerance of immigrants entering the country during this period. Immigrants entering between August 2, 1965, and February 29, 1968, also take significantly less time to find first jobs than in other periods. One possible reason is that there is already a good-sized amount of immigrants settling in the country, and that intra-ethnic social ties or networks enable them to find jobs more quickly than immigrants of earlier periods. Another possible reason is that most of these

6. This analysis has also been redone to include only respondents who provide an accurate sequence of dates of arrival and employment, to test the robustness of the empirical results, and the results are consistent with the ones presented in Table 2. Power analysis has also been performed using SAS's phpow and STATA's stpower cox, and the required estimated numbers of events and sample size are all satisfied (Cantor 2003; Cleves et al. 2010). 
immigrants (about 60 per cent) are engaged in low-ranked jobs (for example, craft, and related or plant and machine occupations; 65 per cent below SIOPS 35), which do not require too much qualification and time for them to find a job. Individuals who enter after the period of July 9, 1988, take the longest duration to find the first job, when compared to individuals entering in previous periods. This is likely because of less favourable economic conditions and lower public acceptance of ethnic diversity and integration in the UK during Margaret Thatcher's administration.

The third model of Table 2 displays the results of the age-to-event function. The random term is significant. The estimates of some variables show some departures from the coefficients of the previous two models. Females are significantly less likely to find first jobs than males. English fluency becomes a significant factor in predicting immigrants' speed to first job, with being fluent in the English language increasing their speed over lack of fluency in the language. The qualification coefficients turn out all significant and negatively signed. The human capital argument, thus, becomes not supported. Furthermore, immigrants who are attending some sort of education program during their job search turn out to be taking significantly less time to find their first job than those who are not. This is likely because a majority of the analytical sample is under age 20 at time zero, and finds a job within a month, causing a large number of job seekers aggregating in early time points (when using age as the time scale as the effect of attained age is being absorbed into the unspecified baseline hazard; Machin et al. 2006).

Table 3 presents the linear regression estimates of occupational scores of immigrants who have successfully obtained a job at the end of the observation window. Both models show similar results in predicting immigrants' occupational score. However, the linear mixed model consists only of immigrants who choose to work; the estimates on their occupational scores have been underestimated, as the lambda term in the Heckman model is significant and negatively signed, suggesting there are (unobserved) factors that make immigrants' participation more likely to be associated with low occupational prestige score or attainment of first employment. The estimated average on occupational score in the Heckman model (about 33) becomes significantly larger than the linear model (about 29), while controlling other variables, indicating the selection was biasing down the estimated average of immigrants' occupational attainment. Nonetheless, both scores suggest that the first jobs immigrants attain tend to be low-end jobs. The marginal model in Model II shows all selection variables are negatively significant, proving that having one extra child and being Pakistani or Bangladeshi immigrants decrease immigrants' probability of being in work.

Regarding ethnicity, Bangladeshis are the most significantly likely to end up finding low-end jobs for their first employment in Britain, followed by Black African/Black Caribbean/Black Other immigrants. In terms of age at job entry, the older the immigrants seeking their first job, the more likely there will be a slight improvement in their occupational attainment. Individuals who are better qualified are more likely to engage in better occupations or higherranked jobs than those who are not. The occupational score for immigrants with university/polytechnic degrees has a better occupational outcome than all other degree holders whereas immigrants with no education have the least scores, suggesting that they are primarily engaged in low-prestige manual jobs. In terms of period of arrival, for immigrants arriving between March 1, 1968, and December 31, 1972, there is a slight improvement in their occupational attainment over immigrants arriving in other periods, even though they are still mostly engaged in low-ranked manual jobs, such as craft and related or plant and machine occupations.

\section{Discussion}

This study seeks to disentangle the effects of time, qualification backgrounds, spatial differences, and the context of time-periods on how long it takes immigrants in Britain/UK to become employed for the first time after arrival, and whether they are more likely to be engaged in low-end or high-end jobs for their first post-immigration employment from a lifecourse perspective. The findings illustrate that the time in people's life (i.e., individual time, generational time, and historical time) when immigrants come to settle in a new country is important in explaining their economic trajectory in a host country, on top of their personal attributes. This helps to demonstrate the usefulness of thinking about how immigrants seek their first job after arriving in terms of Britain/UK employment conditions, and the transferability of their job skills. The study also acknowledges that immigrants who can adapt and who are more qualified, and seek to enhance their employment opportunities through (higher) education training, will find (better) jobs in their host country.

However, because the study of labour market transition(s) of immigrants from arrival to (un)employment and out of the labour force involves many dynamic factors and is a complicated task, and that the dataset used for this 
Table 3. Linear Regression Analysis of SIOPS.

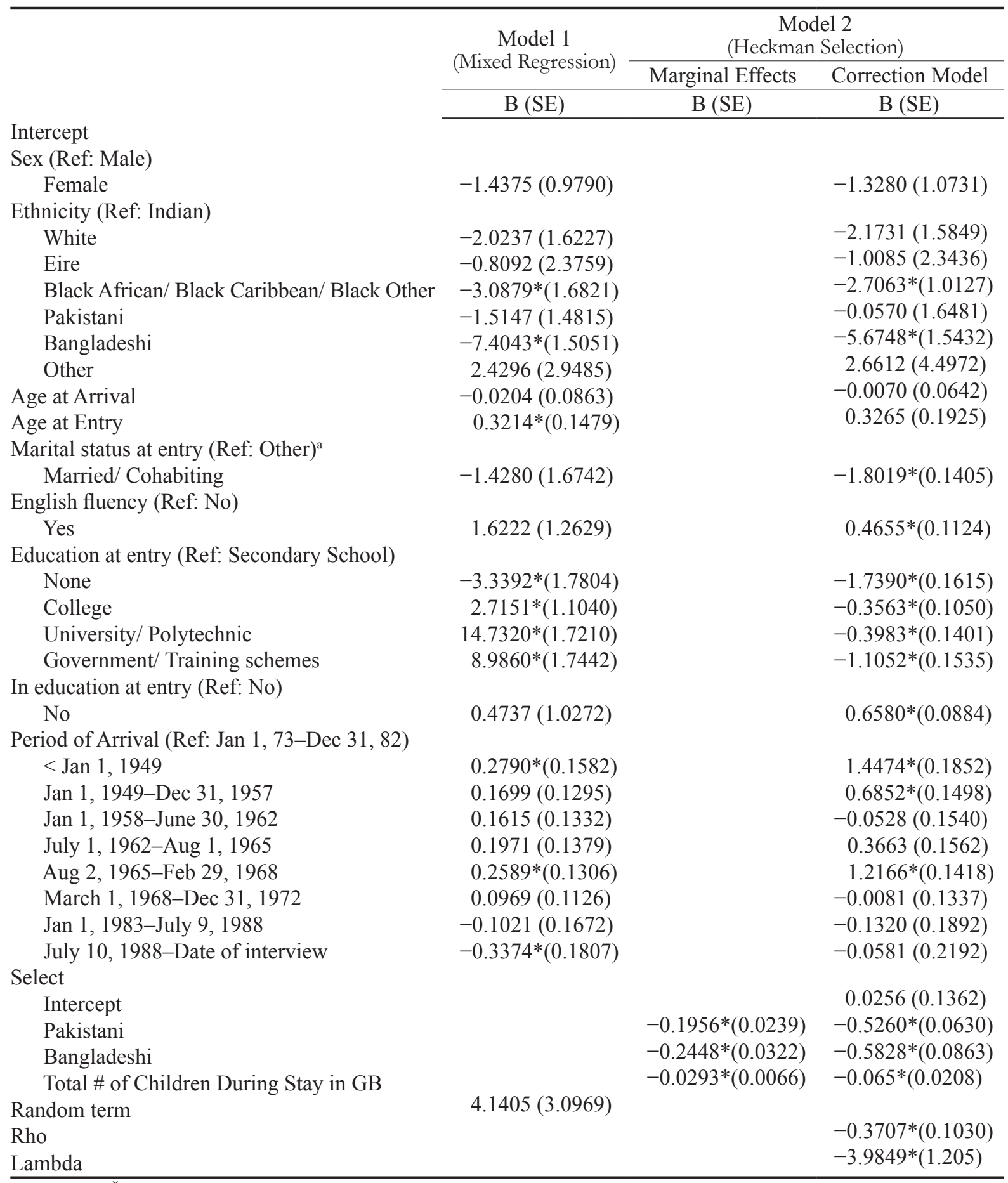

Note: Dunn-Šidák correction is employed for multiple comparisons. For sex, age at arrival, age at entry, marital status, current school participation and English fluency, the 0.05 significance level $(*)$ is used. For ethnicity and country of origin, $\alpha$ is set to 0.35 and the calculated $\beta$ is 0.07 whereas for level of education and period of arrival, $\alpha$ is set to 0.20 and 0.50 with $\beta$ becoming 0.05 and 0.08 , respectively.

a. Because of the sample sizes for economically active individuals who are divorced, separated, and widowed are small, they are grouped together with those who are independent and single. They are labelled as Other in the marriage reference category. 
study has small sample sizes for some categories, further studies are necessary. As a result, we do not want to be too quick to conclude on our findings and say that potentially interesting factors have no effect on time to first employment. Additionally, because this is a single-spell duration study, the results obtained only capture the picture of one duration period. Estimates may underestimate or overestimate immigrants' employment progression status in their host country, as we cannot truly answer whether an ethnic or transitional penalty exists for different ethnic groups, and as we cannot demonstrate if immigrants are able to find a job related to their qualification background prior to their entry to the UK (or Britain). The reason is because it is likely that the first job immigrants have is a temporary job, which is followed by subsequent changes of employment, changing between unemployment and employment, and various kinds of employment before finally landing "skill-matching" jobs (Fuller 2011). As a result, further analysis needs to be done to capture the temporal development of immigrants" employment from a true life course perspective, by doing sequence or multi-spell duration analysis, because such techniques allow us to model the temporal sequence of events, and see the typical length of time it takes immigrants to get a skill-matching job after arrival in newly settled country, and determine if the ethnicity, the levels of human/social capital they have, the location they live in, and the time period they move to a new country make a difference.

\section{References}

Alba, R., and V. Nee. 2005. Remaking the American Mainstream: Assimilation and Contemporary Immigration. Cambridge, MA: Harvard University Press.

Allison, P.D. 1984. Event History Analysis: Regression for Longitudinal Event Data. Sage University Papers Series on Quantitative Applications in the Social Sciences 07-046. Thousand Oaks, CA: Sage.

- 2010. Survival Analysis Using SAS: A Practical Guide. 2nd edn. Cary, NC: SAS Institute Inc.

Ahamad, B., M. Roberts, J. Sobkow, and D. Boothby. 2003. An index of the employment opportunities for new immigrants, based on skills transferability and occupational barriers. Strategic Policy Working Paper Series (Cat. No. HS3-1/586-04-04E). Quebec: Human Resources and Skills Development Canada.

Anwar, M. 2003. "New commonwealth" migration to the UK, in The Cambridge Survey of World Migration, edited by R. Cohen. Cambridge (UK): Cambridge University Press, pp. 274-278.

Barnett, H. 2002. Constitutional and Administrative Law. New York: Routledge.

Beaudoin, C.E., and E. Thorson. 2004. Social capital in rural and urban communities: Testing differences in media effects and models. Journalism \& Mass Communication Quarterly 81(2):378-399.

Bjørnstad, R. 2006. Learned helplessness, discouraged workers, and multiple unemployment equilibria. Journal of Socio-Economics 35:458-475.

Cantor, A.B. 2003. SAS Survival Analysis Techniques for Medical Research. 2nd edn. Cary, NC: SAS Institute Inc.

Castles, S., and G. Kosack. 1973. Immigrant Workers and Class Structure in Western Europe. London: Oxford University Press.

Clark, K., and S. Drinkwater. 2008. The labour-market performance of recent migrants. Oxford Review of Economic Policy 24(3):495-516.

Cleves, M., R.G. Gutierrez, W. Gould, and Y.V. Marchenko. 2010. An Introduction to Survival Analysis Using Stata. 3rd edn. College Station, TX: Stata Press.

Cutts, M. 2000. The State of the World's Refugees 2000: Fifty Years of Humanitarian Action. New York: Oxford University Press.

Daye, S.J. 1994. Middle-class Blacks in Britain: A Racial Fraction of A Class Group or A Class. Basingstoke (UK): Macmillan.

Directgov. 2010. Nationality and citizenship. http://www.direct.gov.uk/en/Governmentcitizensandrights/ LivingintheUK/DG_10015894 (retrieved May 2, 2010). 
Dunn, O.J. 1961. Multiple comparisons among means. Journal of the American Statistical Association 56:52-64.

Dunnett, C.W. 1964. New tables for multiple comparisons with a control. Biometrics 20(3):482-491.

England, P. 1997. Comparable Worth: Theories and Evidence. New York: Aldine.

Fuller, S. 2011. Immigrant employment trajectories and outcomes in the first settlement years: A sequence-oriented approach. Center of Excellence for Research on Immigration and Diversity Working Paper Series (No. 11-07). British Columbia: Metropolis British Columbia.

Ganzeboom, H.B.G., and D.J. Treiman. 1996. Internationally comparable measures of occupational status for the 1988 International Standard Classification of Occupations. Social Science Research 25:201-239.

Giddens, A., and S. Griffiths. 2006. Sociology. 5th edn. Cambridge (UK): Polity.

Golder, M. 2012. Selection models. Methods IV: Advanced Quantitative Analysis Syllabus. https://files.nyu.edu/ $\mathrm{mrg} 217 /$ public/selection.pdf (retrieved January 5, 2012), pp. 1-15.

Grenier, G., and L. Xue. 2009. Duration of access of Canadian immigrants to the first job in intended occupation. Paper presented at the Statistics Canada Socio-Economic Conference. Gatineau, QC (May 4-5).

Heath, A., and S.Y. Cheung. 2006. Ethnic penalties in the labour market: Employers and discrimination. Department for Work and Pensions Research Report 341. Leeds: Corporate Document Services.

Heckman, J. 1979. Sample selection bias as a specification error. Econometrica 47:153-161.

Heron, M.P. (2001). The Occupational Attainment of Caribbean Immigrants in the United States, Canada, and England. New York: LFB Scholarly Publishing.

Hofferth, S.L., and J. Iceland. 1998. Social capital in rural and urban communities. Rural Sociology 63:574-598.

Hutchison, E.D. 2004. Dimensions of Human Behavior: The Changing Lifecourse. Thousand Oaks, CA: Pine Forge Press.

Kleinbaum, D.G., and M. Klein. 2005. Survival Analysis: A Self-Learning Text. 2nd edn. Dordrecht (Netherlands): Springer.

Kogan, I., and M. Unt. 2008. The role of vocational and specificity of educational credentials for labor market entry in Estonia and Slovenia. International Sociology 23(3):389-416.

Laird, N.M., and J.H. Ware. 1982. Random-effects models for longitudinal data. Biometrics 38:963-974.

Layton-Henry, Z. 2004. Britain: From immigration control to migration management, in Controlling Immigration: $A$ Global Perspective, edited by W. Cornelius, T. Tsuda, P. Martin, and J. Hollifield. 2nd edn. Stanford, CA: Stanford University Press, pp. 297-333.

Lin, N., R.S. Burt, and K. Coo. 2001. Social Capital: Theory and Research. New York: Aldine de Gruyter.

Lochhead, C. 2003. The transition penalty: Unemployment among recent immigrants to Canada. Ottawa: Canadian Labour and Business Center.

Machin, D., Y.B. Cheung, and M.K.B. Parmar. 2006. Survival Analysis: A Practical Approach. 2nd edn. Hoboken, NJ: Wiley.

Mckay, S. 1997. Final steps in constructing the family and working lives survey data archive: A research note. Social Security Unit, Center for Research in Social Policy, Loughborough University (UK).

Ochsen, C. 2009. Regional labor markets and aging in Germany. Thünen-Series Working Paper 102. Institute of Economics, University of Rostock (Germany).

Oreopoulos, P. 2009. Why do skilled immigrants struggle in the labor market? A field experiment with six thousand resumes. National Bureau of Economic Research Working Paper Series (Cat. No. 15036). Cambridge, MA: National Bureau of Economic Research, Inc. 
Pastor, M., and E.A. Marcelli. 2000. Social, spatial, and skill mismatch among immigrants and native-born workers in Los Angeles. International Adult Literacy Survey Monograph Series 1. San Diego: Center for Comparative Immigration Studies.

Raijman, R., and M. Semyonov. 1995. Modes of labor market incorporation and occupational cost among new immigrants to Israel. International Migration Review 29(2):375-393.

1997. Gender, ethnicity and immigration: Double disadvantage and triple disadvantage among recent immigrant women in the Israeli labor market. Gender and Society 11:108-125.

Reid, M. 1982. The Secondary Banking Crisis: 1973-75. London: Macmillan.

Reitan, E.A. 2003. The Thatcher Revolution: Margaret Thatcher, John Major, Tony Blair, and the Transformation of Modern Britain, 1979-2001. Lanham, MD: Rowman and Littlefield.

Reitz, J.G. 2007. Immigrant employment success in Canada, part I: Individual and contextual causes. Journal of International Migration and Integration 8(1):11-36.

Reskin, B.F., and P. Roos (eds.). 1990. Job Queues, Gender Queues: Explaining Women's Inroads into Male Occupations. Philadelphia: Temple University Press.

Robinson, V. 2003. The migraiton of East African Asians to the UK, in The Cambridge Survey of World Migration, edited by R. Cohen. Cambridge (UK): Cambridge University Press, pp. 331-336.

Rohwer, G. 1996. A practical introduction to the family and working lives survey, part I: Introduction and data handling. Transition Data Analysis User's Manual. London: Department for Education and Employment.

Sanders, J., V. Nee, and S. Sernau. 2002. Asian immigrants' reliance on social ties in a multiethnic labor market. Social Forces 81(1):281-314.

Shields, J., K. Rahi, and A. Scholtz. 2006. Voices from the margins: Visible minority immigrant and refugee youth experiences with employment exclusion in Toronto. Joint Center of Excellence for Research on Immigration and Settlement Working Paper Series 47. York, ON: Ontario Metropolis Centre.

Singer, J.D., and J.B. Willett. 2003. Applied Longitudinal Data Analysis: Modeling Change and Event History. New York: Oxford University Press.

Solomos, J. 1989. Race and Racism in Contemporary Britain. Hampshire (UK): Macmillan.

Spencer, I.R. 1997. British Immigration Policy Since 1939. New York: Routledge.

Stein, D. 1995. People Who Count: Population and Politics, Women, and Children. London: Earthscan Publications.

Syed, J. 2008. Employment prospects for skilled migrants: A relational perspective. Human Resource Management Review 18:28-45.

Webster, W. 1998. Imagining Home: Gender, "Race," and National Identity, 1945-64. London: UCL Press.

—. 2006. Transnational journeys and domestic histories. Journal of Social History 39(3):651-666.

Wooldridge, J.M. 2008. Econometric Analysis of Cross Section and Panel Data. 2nd edn. Cambridge, MA: MIT Press. 